\section{CAG research update}

Derek McKay PhD

Chair, CAG Research Committee

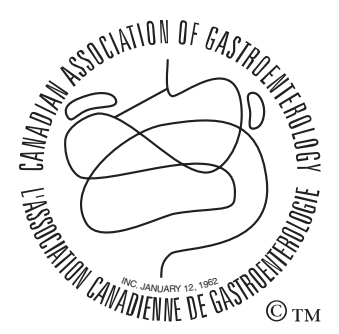

En français voir page 531
Some exciting developments and changes have occurred $\checkmark$ since the May report from the Canadian Association of Gastroenterology (CAG) Research Committee, which I am pleased to share with you.

\section{CAG/ALTANA RESIDENT RESEARCH TRAINING AWARDS}

This new initiative for 2004 is intended to provide a foundation for clinical research activities during residency to encourage continued involvement in research after completion of training. We would like to thank ALTANA Pharma Inc for their sponsorship and congratulate the following successful candidates:

- Ian Bookman, University of Toronto, Toronto, Ontario "The Pathophysiology of Non-Alcoholic Fatty Liver Disease: Characterising the Genetic, Biochemical and Clinical Effects of Insulin Resistance in NASH versus Simple Fatty Liver" Supervisor: E Jenny Heathcote

- Gil Kaplan, University of Calgary, Calgary, Alberta "Population-based Study of the Epidemiology of Primary Sclerosing Cholangitis in the Calgary Health Region" Supervisor: Samuel Lee

- Joe Pham, McMaster University, Hamilton, Ontario "Z-line Appearance at Endoscopy: Association with Histological Features of Endoscopy Negative Reflux Disease" Supervisor: David Armstrong

- Frances Tse, McGill University, Montreal, Quebec "Development of an Objective Scoring System for the Performance of Diagnostic Upper Gastrointestinal Endoscopy" Supervisor: Alan Barkun

We hope to continue to offer this excellent opportunity in the future.

\section{UPDATES ON THE 2004 CAG/CIHR/INDUSTRY FELLOWSHIPS AND GRANTS}

New Investigator Establishment Grant

The Canadian Digestive Health Foundation (CDHF)/ CAG/ALTANA New Investigator Establishment Grant was awarded to Mark Ropeleski, MD, of Queen's University,
Kingston, Ontario. Subsequently, Dr Ropeleski succeeded in securing three years of funding under the Crohn's and Colitis Foundation of Canada's (CCFC) Grants in Aid of Research Program, and therefore declined the CAG grant. We congratulate Mark and are delighted to be able to bring the membership this news - clearly, CAG research funds are being directed towards worthy recipients. The New Investigator Establishment Grant was subsequently offered to Isabella Tai, MD, of the University of British Columbia, Vancouver, British Columbia, for her project titled "Genome-wide analysis reveals a novel gene involved in chemotherapy resistance in colorectal cancers". Dr Tai accepted the award.

CAG/CIHR/AstraZeneca Research Initiative Award After accepting the CAG/CIHR/AstraZeneca Research Initiative Award award for 2004, recipient Dr Kathryn Howe has decided to pursue a career in medicine. We wish Kathryn much success in medical school and during her subsequent specialty training and hope for a return to gastrointestinal (GI)related research at an opportune time.

\section{CAG/CIHR/CCFC Fellowships}

We are happy to report that the above fellowships partnered by our long-time supporter the CCFC, have moved from oneyear awards (with possible one year renewal) to a confirmed two-year funding period consistent with most other CAG/CIHR/Partner funded awards. We thank the CCFC for their continued commitment to this program.

\section{TRAINEES MARK YOUR CALENDARS}

\section{Research Topics Meeting}

A reminder to graduate students, residents and postdoctoral fellows that Research Topics in GI Disease IV will be held October 22-24, 2004 in King City, Ontario. Abstracts must be submitted online at the CAG Web site no later than September 8, 2004. For more details please visit the CAG Web site <http://www.cag-acg.org/meetings/form_final.htm>

\section{Fellowship and grant applications}

The deadline for receipt of all applications for the 2005 CAG fellowships and grants is October 15, 2004. Details and applications are posted under the Research page of the CAG Web site <http://www.cag-acg.org/research/index.htm> 


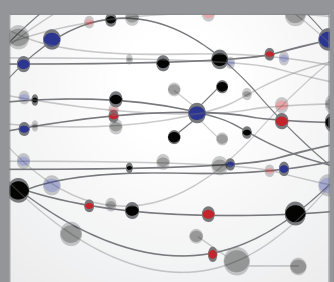

The Scientific World Journal
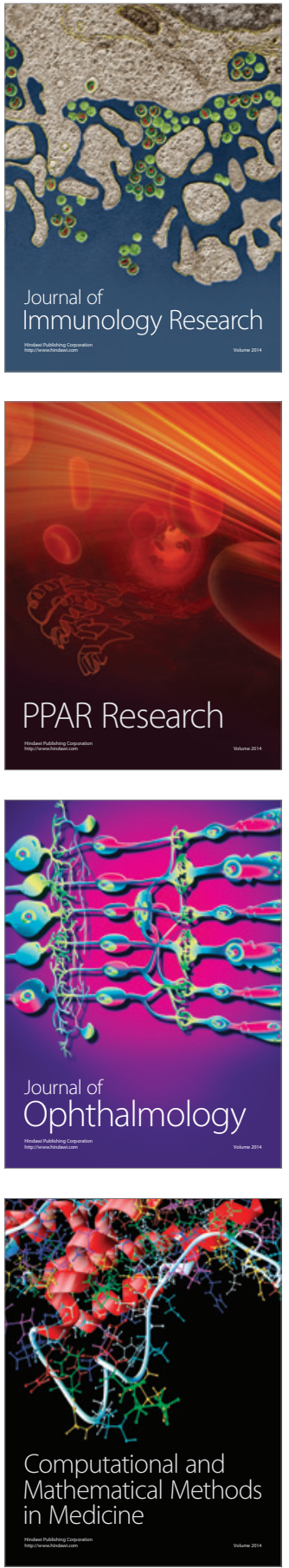

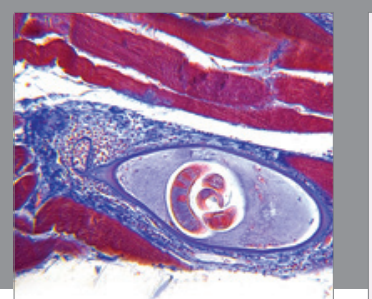

Gastroenterology Research and Practice

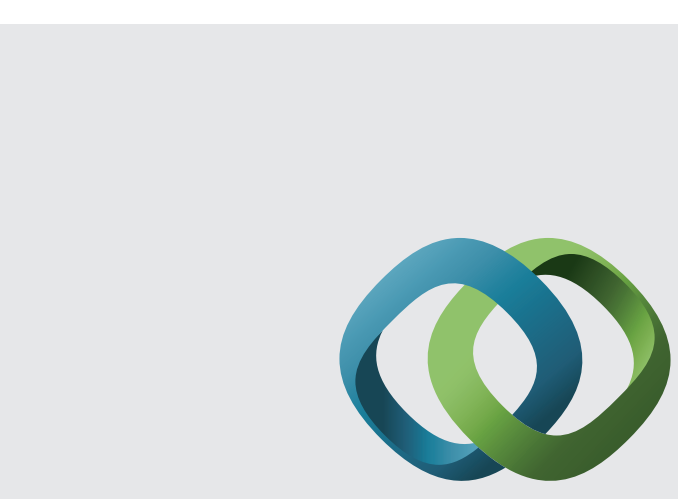

\section{Hindawi}

Submit your manuscripts at

http://www.hindawi.com
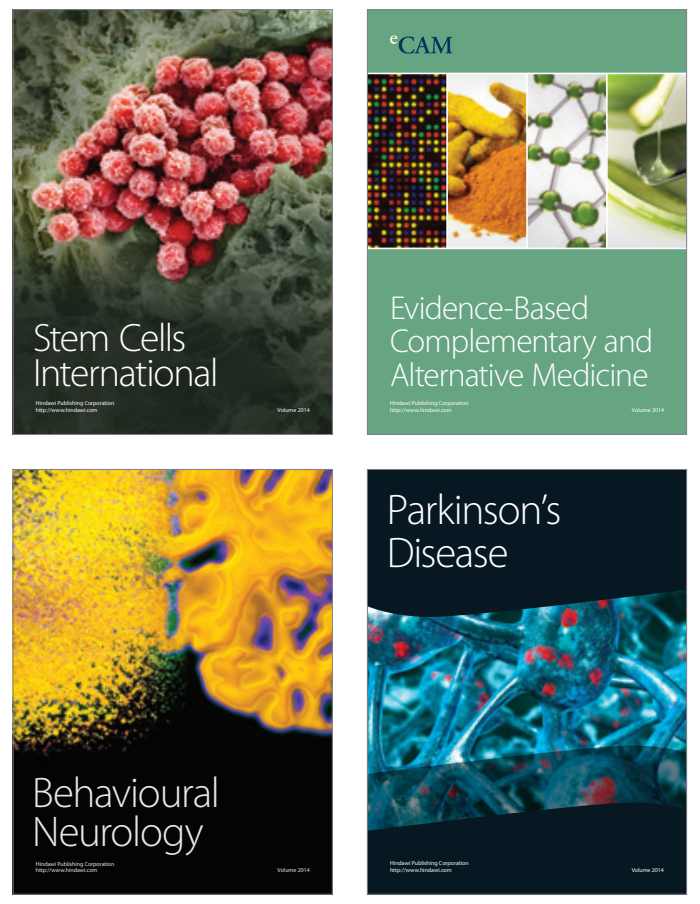
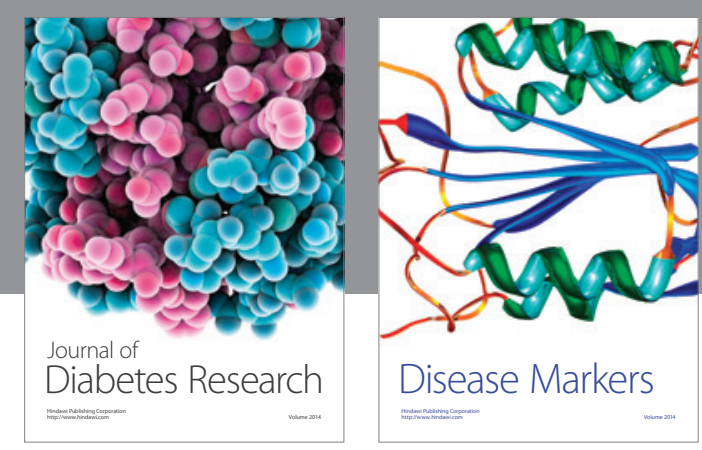

Disease Markers
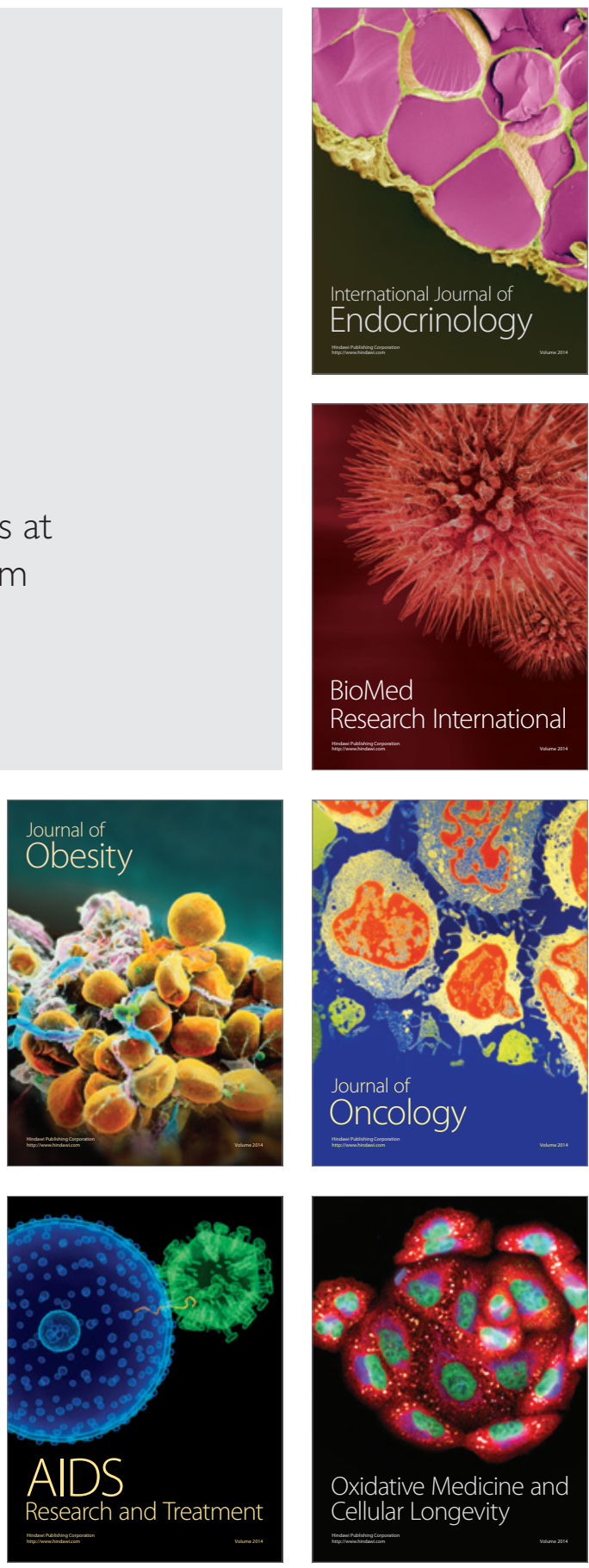